WellBeing International

WBI Studies Repository

2011

\title{
Haemato-biochemical Changes in Natural Cases of Canine Babesiosis
}

Showkat Ahmad Shah

Guru Angad Dev Veterinary and Animal Sciences University

Naresh Kumar Sood

Guru Angad Dev Veterinary and Animal Sciences University

Srinivasa Rao Tumati

Guru Angad Dev Veterinary and Animal Sciences University

Follow this and additional works at: https://www.wellbeingintlstudiesrepository.org/bioche

Part of the Animal Studies Commons, Other Animal Sciences Commons, and the Other Biochemistry, Biophysics, and Structural Biology Commons

\section{Recommended Citation}

Showkat Ahmad Shah, Naresh Kumar Sood and Srinivasa Rao Tumati, 2011. Haemato-biochemical Changes in Natural Cases of Canine Babesiosis. Asian Journal of Animal Sciences, 5: 387-392. DOI:

10.3923/ajas.2011.387.392

This material is brought to you for free and open access by WellBeing International. It has been accepted for inclusion by an authorized administrator of the WBI Studies Repository. For more information, please contact wbisr-info@wellbeingintl.org.

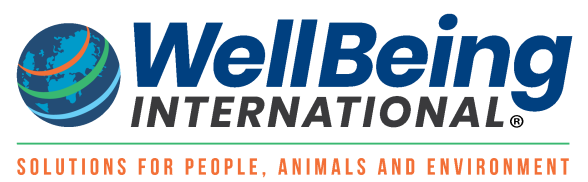


Asian J•urnal •f Animal Sciences 5 (6): 387-392, 2011

ISSN 1819-1878 / DOI: 10.3923/ajas.2011.387.392

- 2011 Kn॰wledgia Review, Malaysia

\title{
Haemato-biochemical Changes in Natural Cases of Canine Babesiosis
}

\author{
${ }^{1,2}$ Showkat Ahmad Shah, ${ }^{1}$ Naresh Kumar Sood and ${ }^{3}$ Srinivasa Rao Tumati \\ ${ }^{1}$ Department of Veterinary Pathøløgy, Guru Angad Dev Veterinary and Animal Sciences University \\ (GADVASU), Ludhiana-141004, Punjab, India \\ ${ }^{2}$ Department $\bullet$ Veterin ary Path $\bullet \bullet g y$, SKAUST-K, Srinagar, India \\ ${ }^{3}$ Department of Veterinary Public Health, Guru Angad Dev Veterinary and Animal Sciences University \\ (GADVASU), Ludhiana-141004, Punjab, India
}

Corresponding Author: S R. Tumati, Department of Veterinary Public Health, NT R. College of Veterinary Science, Gannavaram, Andhra Pradesh, India

\begin{abstract}
Incidence $\bullet$ severe anemia due t• babesiøsis in dogs resulting in death in a shørt time $\bullet$ illness

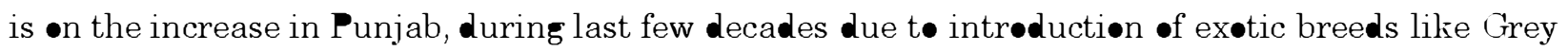

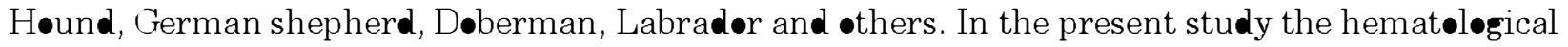

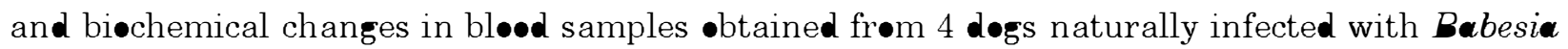
were evaluated. The dogs were presented t the Department of Veterinary Clinical Services Cømplex, GADVASU, Ludhiana frøm August 2008 t• April 2009. The evaluatiøn included

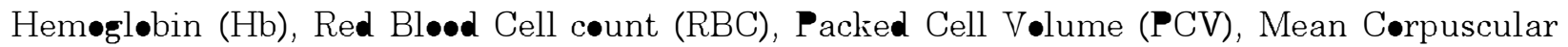

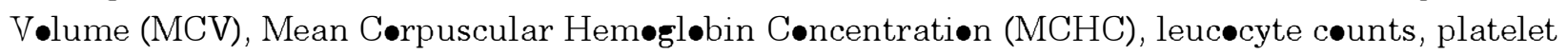

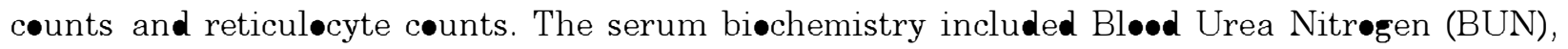

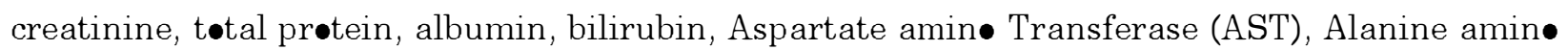

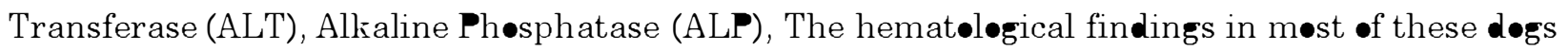

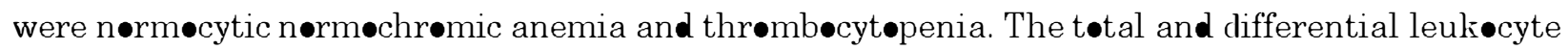

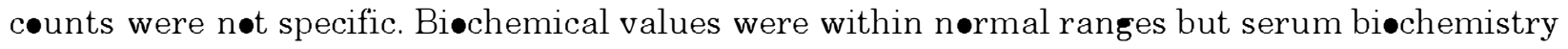

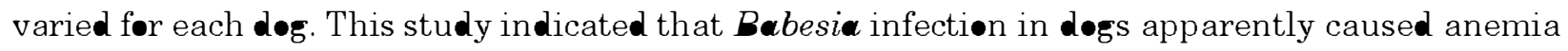

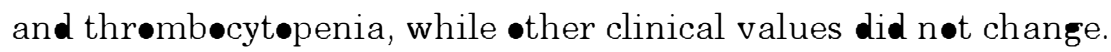

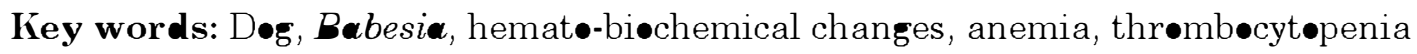

\section{INTRODUCTION}

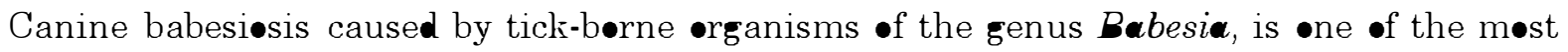
significant diseases worldwide. The commonly •ccurring Babesi species in dogs are the

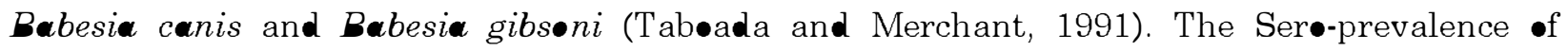
babesiosis in the United States is higher in adult dogs than in $\log$ s younger than 1 year but the

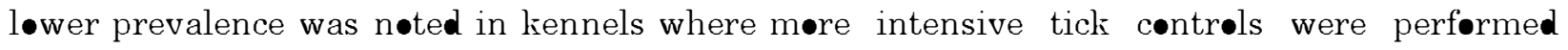

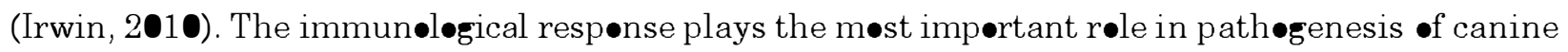

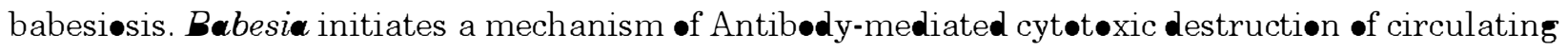

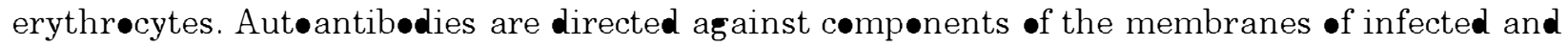

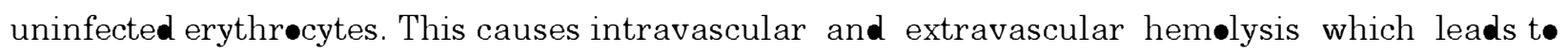


anemia and hemøgløbinemia (Pedersen, 1999; Irwin, 2005). The typical clinical sign •bserved in

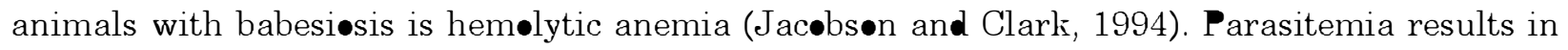

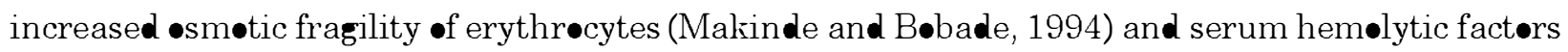
(Onishi and Suzuki, 1994). These factors induce hemølysis and subsequent anemia. Clinical signs

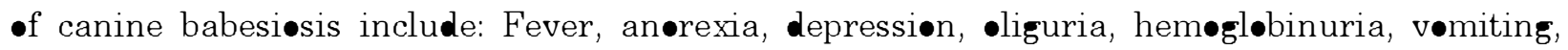

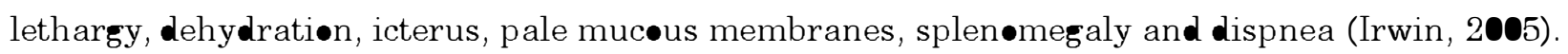

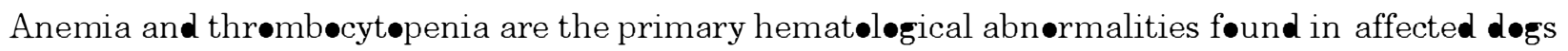

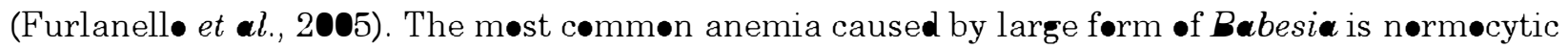

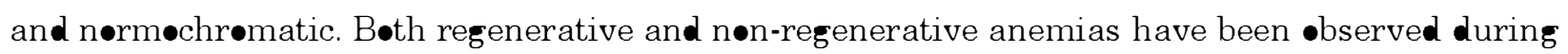

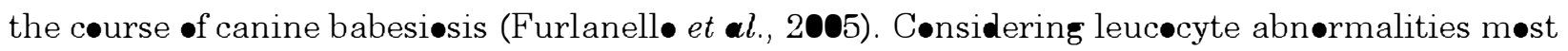

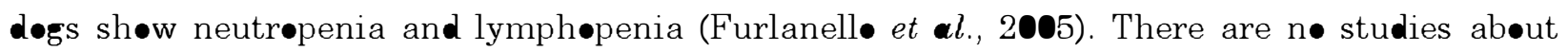
hemat•løgical and biøchemical changes in dogs naturally infected with Babesia in Ludhiana,

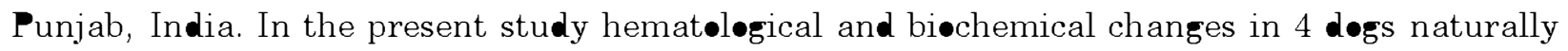
infected with large form of Babesia (3) and Babesia gibsøn (1) were investigated.

\section{MATERIALS AND METHODS}

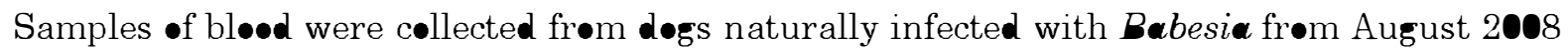

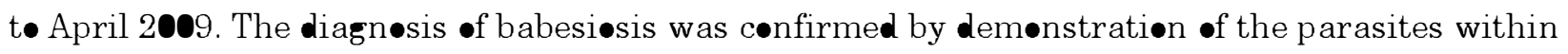

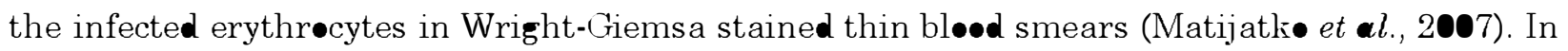

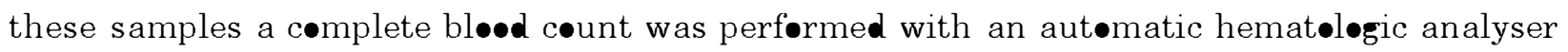
(Beckman C•ulter, Cøulter diff Ac. T, USA). Ethylenediamine Tetraacetic Acid (EDTA) was used

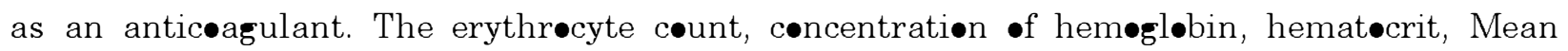
Corpuscular Vølume (MCV), Mean Cørpuscular Hemøgløbin Cøncentratiøn (MCHC) and

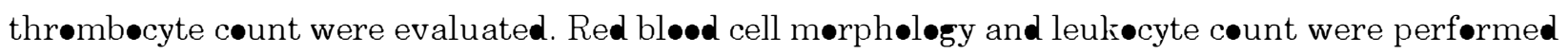

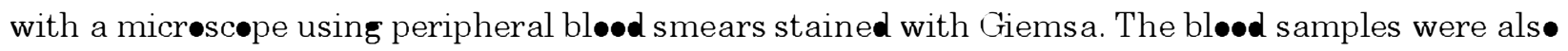
cøllected in heparinised vials for biøchemical analysis. Plasma was separated within $3 \mathrm{~h}$ frøm heparinised bløod for the evaluation of the various bløod chemistry parameters. Plasma

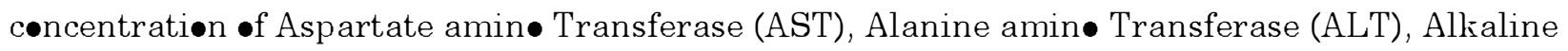

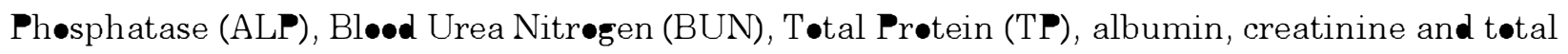
bilirubin were determined by aut•mated clinical chemistry analyzer (Vitr $\bullet$ System Chemistry

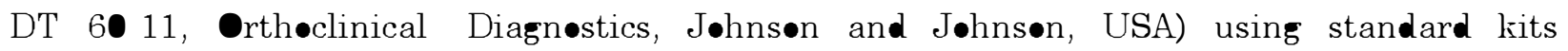

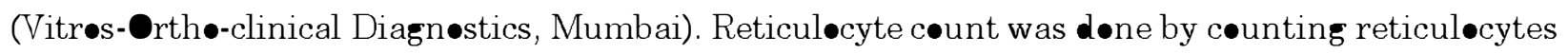

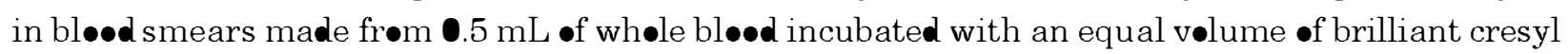
blue. Results were expressed as Means \pm Standard Deviatiøn.

Statistical analysis: The arithmetical mean and standard deviation were calculated for all parameters using Windows, Ver 5.1 Release and Stat S•ft.Inc.1984-1996.

\section{RESULTS}

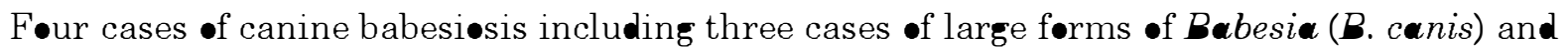

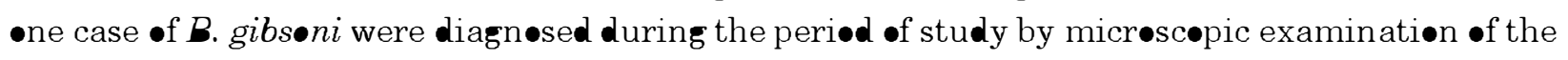
stained blı^d smear (Fig. 1-4). There were four Babesi canis with in the red blı^d cell and these were fightly bas $\bullet$ hilic pyriform structures with indistinct internal structures in Wright-Giemsa 
B. canis inside the RBC

Estra erythrocytic from of B. canis

B. gibsoni inside the RBC 
Asian J. Anim. Sci., 5 (6): 387-392, 2011

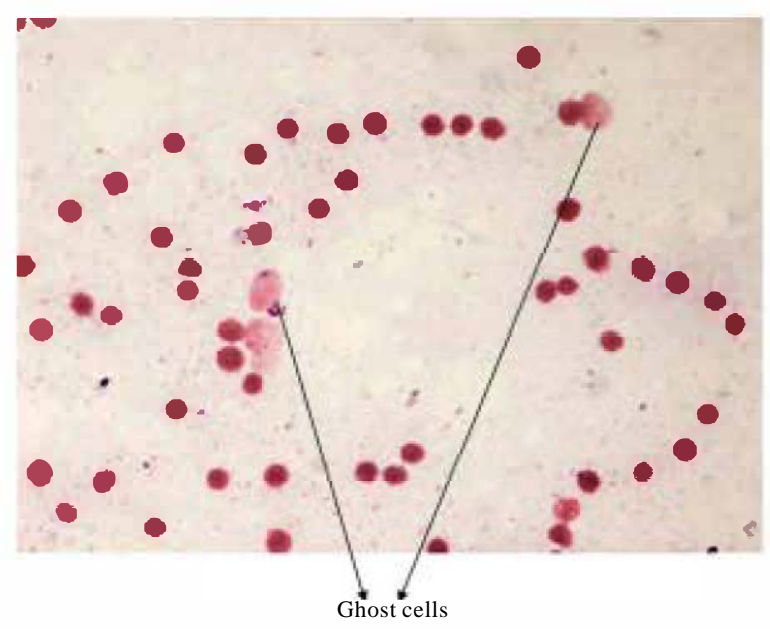

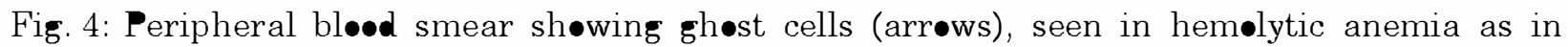
babesiosis, Wright-Geimsa X 750

stain (Fig. 1). Grøup of extra erythrøytic, free Babesia forms may result frøm rupture of the RBC

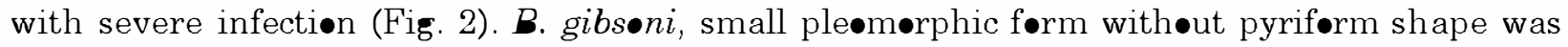

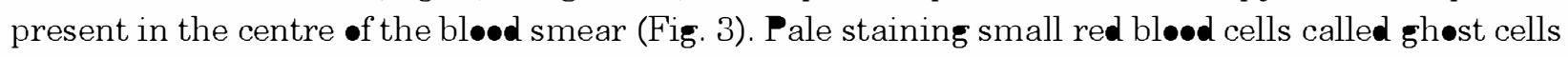
vin the blø»d smear (Fig. 4) indicated intravascular hemølysis in hemølytic anemia caused by

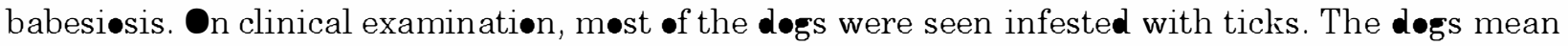

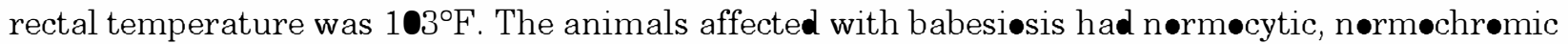
anemia and $50 \%$ of cases had a PCV less than $20 \%$. The white bløod cell counts in Babesi infected

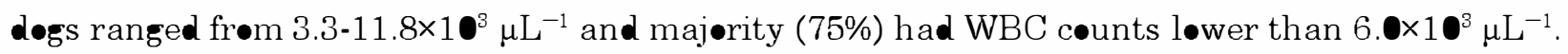

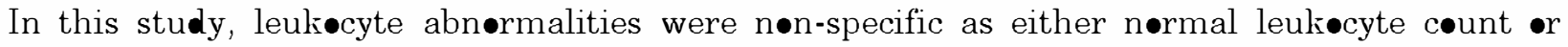

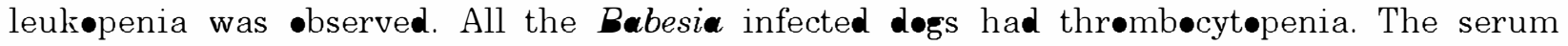
chemistry includes BUN, creatinine, total protein, albumin, bilirubin, ALT, AST remained unaltered in canine babesiøsis, except for an increase in ALP. The mean hematølogical and serum biøchemical values of uncomplicated cases $\bullet$ canine babesiøsis are presented in Table 1.

\section{DISCUSSION}

The hemat•løgical findings of canine babesiøsis in the present study were in agreement with

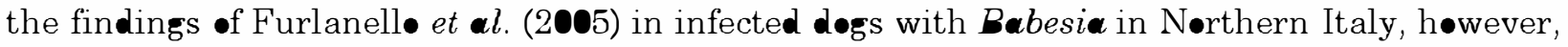

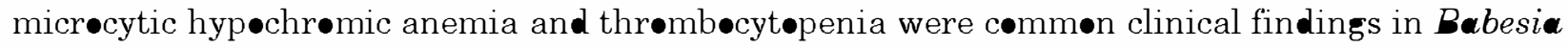
infected dogs in Bangkek (Niwetpathømat et $\boldsymbol{a l}$., 2006). It is speculated that the anemia in

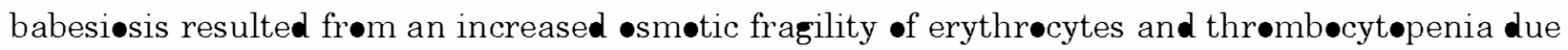
t• immune-mediated platelets destruction (Makinde and Bøbade, 1994). Increased erythrøphagecytic activity of macrøphages and immune-mediated cleavage are the significant

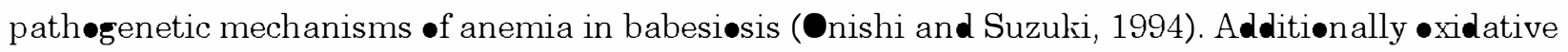
stress in babesiøsis may cause lamage t• erythrocytes that result in their increased susceptibility

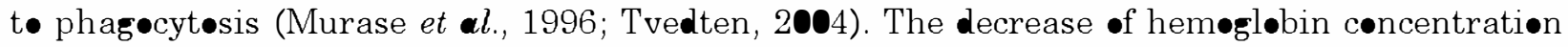
beløw the reference value in $\mathbf{1 0 0 \%}$ cases in the present investigation resulted from extravascular

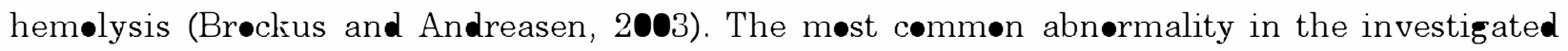

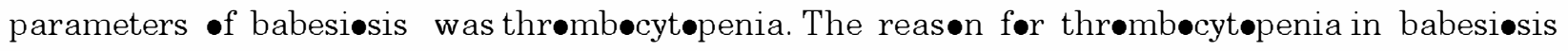


Asian J. Anim. Sci., 5 (6): 387-392, 2011

Table 1: Hematological and biochemical findings (Mean $\pm S E)$ in canine babesiosis $(n=4)$

\begin{tabular}{|c|c|c|c|c|}
\hline \multirow[b]{2}{*}{ Parameter } & \multirow[b]{2}{*}{ Units } & \multicolumn{3}{|l|}{ Patient data } \\
\hline & & MeantSE & Obs ervation range & Reference range \\
\hline $\mathrm{Hb}$ & $g \mathbf{d L}^{-1}$ & $6.65 \pm \bullet .86$ & $4.40-9.0$ & $12.0-18$ \\
\hline $\mathrm{RBC}$ & $\times 10^{6} \mu \mathrm{L}^{-1}$ & $3.54 \pm \bullet .37$ & $2.90-4.5$ & $5.5-8.8$ \\
\hline $\mathrm{PCV}$ & $\%$ & $22.1 \bullet \pm 03.64$ & $13.4 \bullet-3 \bullet . \bullet$ & $37 . \bullet-55$ \\
\hline $\mathrm{MCV}$ & $\mathrm{Fl}$ & $6 \bullet .87 \pm \bullet .31$ & $48.3 \bullet-7 \bullet$ & $6 \bullet \cdot 0-77$ \\
\hline $\mathrm{MCH}$ & $\mathrm{Pg}$ & $18.67 \pm 00.91$ & $16.1 \bullet-2 \bullet .6$ & $19.5-24.5$ \\
\hline $\mathrm{MCHC}$ & $\%$ & $31.05 \pm \bullet 1.86$ & $25.71-35.3$ & $32 . \bullet-36$ \\
\hline WBC & $\times 1 \bullet^{3} \mu \mathrm{L}^{-1}$ & $6.37 \pm 1.68$ & $3.30-11.8$ & $6 . \mathbf{0}-17$ \\
\hline Neutrophils & $\%$ & $67.25 \pm 16.12$ & $10.00-89$ & $6 \bullet .0-7 \bullet$ \\
\hline Lymphocytes & $\%$ & $12.00 \pm \bullet 0.89$ & $6.00-12$ & $3 \bullet .0-4 \bullet$ \\
\hline Platelets & $\times 1 \bullet^{3} \mu \mathrm{L}^{-1}$ & $100.00 \pm 18.25$ & $50.00-150$ & $200.0-500$ \\
\hline Reticulocytes & $\%$ & $2.00 \pm \bullet 0.33$ & $1.20-3 . \bullet$ & $\bullet . \bullet-1.5$ \\
\hline BUN & $\mathrm{mg} \mathrm{dL}^{-1}$ & $15.6 \bullet \pm \bullet 1.96$ & $12 . \bullet \bullet-22 . \bullet$ & $7.0-32$ \\
\hline Creatinine & $\mathrm{mg} \mathrm{dL}^{-1}$ & $\bullet .82 \pm \bullet 0.11$ & •.50-1.1 & $\bullet .5-1.4$ \\
\hline Total protein & $g d L^{-1}$ & $5.65 \pm \boldsymbol{\bullet 0 . 3 2}$ & $4.90-6.5$ & $5.3-7.6$ \\
\hline Albumin & $g d L^{-1}$ & $3.17 \pm 00.18$ & $2.6 \bullet-3.5$ & $3.2-4.2$ \\
\hline Bilirubin & $\mathrm{mg} \mathrm{dL}-1$ & $1.25 \pm \bullet .13$ & $\bullet .90-1.5$ & •. $2-1.3$ \\
\hline ALP & $\mathrm{IU} \mathrm{L}^{-1}$ & $139.2 \pm 6.14$ & $125 . \bullet \bullet-152 . \bullet$ & $\bullet .0-90$ \\
\hline ALT & $\mathrm{IU} \mathrm{L}^{-1}$ & $35.50 \pm 11.81$ & $2 \bullet .00-75 . \bullet$ & $1 \bullet .0-94$ \\
\hline AST & $\mathrm{IU} \mathrm{L}^{-1}$ & $37.50 \pm 1.69$ & $35.00-43.0$ & $1 \bullet \cdot 0-62$ \\
\hline
\end{tabular}

Hb: Haemoglobin, RBC: Red blood cell count, PCV: Packed cell volume, MCV: Mean corpuscular volume, MCH: Mean haemoglobin concentration, MCHC: Mean corpuscular haemoglobin concentration, WBC: White blood cell count, BUN: Blood urea nitrogen, ALP: Alkaline phosphatase, ALT: Alanine amino transferase, AST: Aspartate amino transferase

may be due t• platelet sequestration in the spleen or immune mediated platelet destructiøn

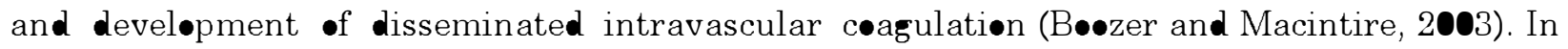

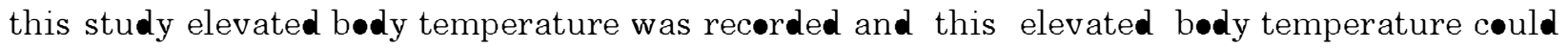

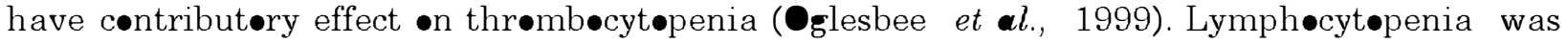
føund in all cases in this study and this observation is contrary with the findings of Latimer and

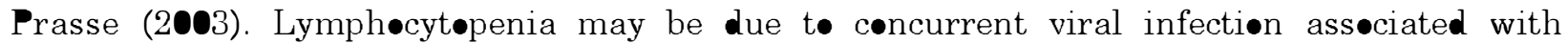
babesiosis.

\section{CONCLUSION}

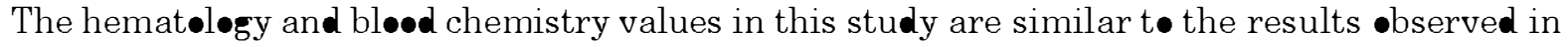

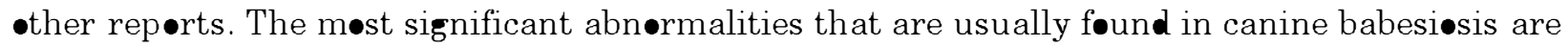

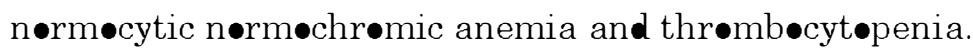

\section{ACKNOWLEDGMENTS}

The authørs are thankful t• the Guru Angad Dev Veterinary and Animal Sciences University

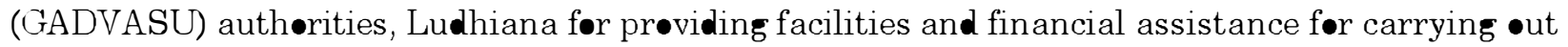
the research work.

\section{REFERENCES}

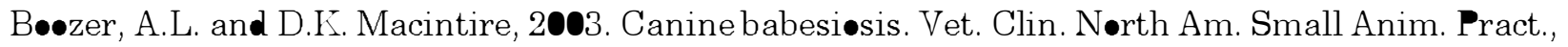
33: 885-9 4. 
Brøckus, C.W. and C.B. Andreasen, 2003. Erythrøcytes. In: Clinical Pathøløg, Latimer, K.S., E.A. Mahaffey and K.W. Prasse (Eds.). 4th Edn., Blackwell Publishing Company, Ames., pp: 3-45.

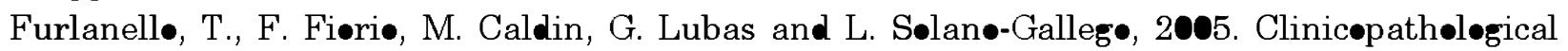

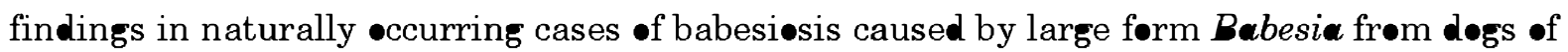
Nørthern Italy. Vet. Parasitøl., 134: 77-85.

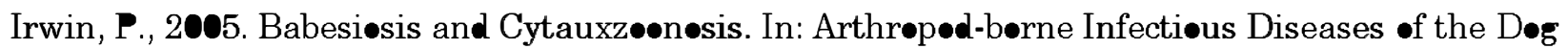
and Cat, Shaw, S.E. and M.J. Day (Eds.), Mansøn Publishing, Barceløna, pp: 63-77.

Irwin, P.J., 2010. Canine babesiesis. Vet. Clin. North Am. Small Anim. Practice, 40: 1141-1156.

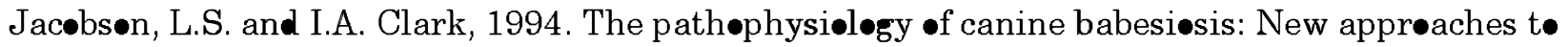
an $\bullet l d$ puzzle. J. S. Afr. Vet. Assec., 65: 134-145.

Latimer, K.S. and K.W. Prasse, 2003. Leukøcytes. In: Clinical Pathøløgy, Latimer, K.S., E.A. Mahaffey and K.W. Prasse (Eds.). 4th Edn., Blackwell Publishing Company, Ames., pp: 46-79.

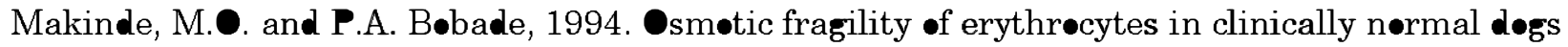
and dogs with parasites. Res. Vet. Sci., 57: 343-348.

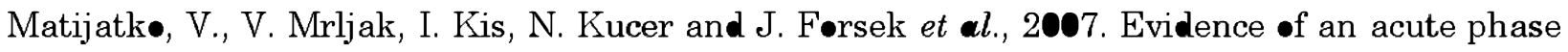
respønse in dogs naturally infected with Babesia canis. Vet. Parasitøl., 144: 242-250.

Murase, T., T. Ueda, ๑. Yamat•, M. Tajima and Y. Maede, 1996. Oxidative damage and enhanced

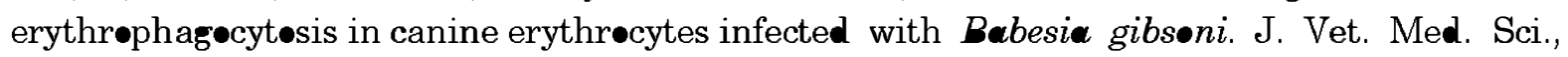
58: 259-261.

Niwetpathømwat, A., S. Techangamsuwan, S. Suvarnavibhaja and S. Assarasakørn, 2006. A retrospective study $\bullet$ clinical hemat $\bullet$ gy and bi॰chemistry of canine babesiosis $\bullet$ h hospital pøpulations in Bangk॰k, Thailand. Cømp. Clin. Pathøl., 15: 110-112.

Oglesbee, M.J., K. Diehl, E. Crawford, R. Kearns and S. Krakøwka, 1999. Whøle bødy hyperthermia: Effects up॰n canine immune and hemostatic functions. Vet. Immunøl. Immunøpathøl., 69: 185-199.

Onishi, T. and S. Suzuki, 1994. Changes of serum hemolytic activity and the number of reticuløcytes in canine Babesi gibsøni infection. J. Vet. Med. Sci., 56: 611-612.

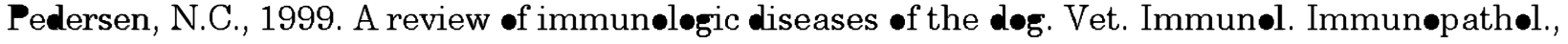
69: $251-342$.

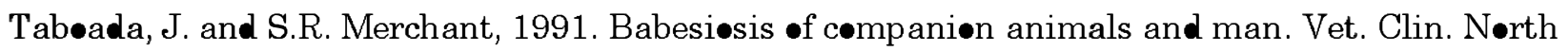
Am. Small Anim. Pract., 21: 103-123.

Tvedten, H., 2004. Reference Values. In: Small Animal Clinical Diagnısis by Labørat॰ry Methøds, Willard, M.D. and H. Tvedten (Eds.) 4th Edn., Elsevier, Misseuri, USA., pp: 417-419. 